\title{
INTEGRATION OF SERBIAN TO ENGLISH TRANSLATION OF PROFESSIONAL AND SCIENTIFIC PAPER TITLES FROM ELECTRICAL ENGINEERING AND ICT REGISTER INTO TRANSLATION TEACHING WITHIN ESP
}

\author{
Darko Kovačević \\ University of East Sarajevo, Faculty of Electrical Engineering/Academy of Music, Bosnia and Hercegovina \\ E-Mail: dax1978@gmail.com
}

\begin{abstract}
In contemporary teaching of ESP, translation teaching presents a component which is important due to numerous reasons. After a general introduction dealing with various ESP issues and an overview of different theoretical views on the role of translation in ESP, the matter of translation of professional and scientific paper titles from Serbian to English as a part of teaching electrical engineering and ICT related ESP is discussed. The discussion includes the main arguments for the integration of such matter into ESP lessons for Serbian speaking learners, the presentation of an analysis based on a corpus of 500 titles of professional and scientific papers from Electrical Engineering and ICT register translated from Serbian into English and its results, as well as the opportunities for the application of such results at ESP lessons, within the integration of the translation of such titles into the translation teaching process. The final overview and some conclusions are given at the end of the paper.
\end{abstract}

Key words: ESP, translation, Serbian, English, title, paper, teaching

\section{INTRODUCTION}

In teaching English for Specific Purposes (ESP) in the present time, there are numerous issues which have to be taken into account even before the actual beginning of the teaching process (lessons) in direct contact with the students. Namely, ESP as a concept involves the necessity of introducing the students to the specificities in use of the English language in different forms of professional or vocational human activities, such as art, medicine, economics, engineering, information and communication technologies etc. Of course, such "specificities" and "use" are far from implying that any form of ESP, regardless of the field of human activity it has been related to, presents a "new" or "special" language, with linguistic concepts radically and drastically different from the ordinary and common English for general purposes which is used for the exchange of information on every day topics. Instead of that, it simply presents a way in which the language is used within the discourse community of professionals in different fields, and is, usually, primarily characterised by the use of specific terminology, and, secondarily, although it is not always the case, by the use of some specific or characteristic linguistic structures and patterns (grouping of words, collocations, sentence patterns, organisation of paragraphs, use of active or passive voice...) 
through which different practical purposes are achieved in various forms of professional communication within a discourse community (condensation and preciseness of information, effect of informational and terminological "exclusiveness" achieved through long complex sentences, demonstration of multidisciplinarity indicators within a textual material...). The two basic assumptions relating to an ESP course at the higher education level are:

- students have already been introduced to general English language through elementary and secondary education and

- students possess appropriate (moderate or advanced) professional knowledge in their field of study in terms of dealing with the terms, concepts and textual (linguistic or discursive) practices in their mother tongue.

Of course, in the practice of teaching ESP, such assumptions often to be at least partially wrong or too idealistic, due to the individual skills, affinities, capacities and previously acquired knowledge which characterises every single student. Because of that, and in relation with the first assumption, it is often necessary to perform a sort of equalisation or harmonisation of the students' knowledge in the initial stages of an ESP course, in terms of general English grammar and vocabulary, and also, at the same time, in relation with the second assumption, to make efforts to assess the level of their professional knowledge and find an appropriate common denominator from which the concepts of the English language relating to the given field of professional or vocational activity might be introduced successfully, through various materials and by means of different methods and techniques. To make an ESP course truly effective and purposeful, it is important for such an "introduction" to occur as soon as possible within the timeline of the course, so that it does not turn into a general English course, similar to the ones the students already attended within the systems of elementary and secondary education.

In teaching ESP, translation is one of the components which requires and deserves to be implemented and fostered constantly. Namely, in terms of mastering specific terminology and linguistic or discourse characteristics of professional texts written in English, the easiest way, at the students' side, is to use the concepts and knowledge they already possess in their mother tongue and apply it in learning the new words or phrases or in dealing with new linguistic or discursive structures and patterns. On the other hand, due to the present-time status of English as the most widespread and universally spoken and written world language, and the constantly growing amount of publications in all fields of human activity which written and published in that language, it is very easy to expect that every person coming from a non-English speaking country and possessing a higher education professional qualification or studying at a faculty in order to obtain it will, in the course of the career be, among the other things, obliged to translate textual materials from and into English on regular basis, both for the purpose of acquiring new information and preparing own textual materials to be read and published abroad. In order to improve the translation capacities and skills of such persons, it is very important to make translation a constant and consistent part of their ESP courses at the university level.

\section{ESP AND TRANSLATION}

Various aspects of using translation in teaching ESP have been elaborated in literature. Prudnikova (2013) expresses the opinion that the main difficulty in teaching ESP is in the fact that teaching must accomplish two goals which are incompatible. The first of such 
goals is the focus of teaching on applied knowledge and practical skills required and necessary for meeting professional communication demands, implying a wide range of terminological and idiomatic language units. On the other hand, the second goal is speech fluency, usually achieved through the implementation of the communicative approach, while, at the same time, performance accuracy, thorough vocabulary study and proper word choice are often neglected, so that the formation of translation and interpretation skills is not developed to the necessary degree.

In terms of practical performance of a course and the translation-related tasks and assignments it should include, she defines and proposes four types of exercises and their purpose, depending on the stage of the study and the type of the selected translation. These four types are:

- linguistic exercises, which improve translation skills and help to solve interpretation tasks in which the differences between general English language and ESP systems are visible;

- conversational exercises, which form the abilities of communication within interpretation and other kinds of bilingual communication;

- operational exercises, which contribute to the recoding of information, and

- mnemonics tasks, which improve automated operational memory of the interpreter.

The conclusion that she makes is that, within ESP courses, translation should be taught as an integral part of a complex approach to an interactive method, presenting a synthesis of tutorials having interactive function and computer linguo-didactics, or in other words, as a synthesis of cognitive and communicative approach to teaching ESP.

Benabdallah (2013) states that the preparing of ESP learners for more specialised communication should be subjected to a planned and strategic instruction so that they could deal with the challenges of global world, and at the same time, attain a better professionalisation. He thinks that translation should not be implemented as a productoriented task by itself, as a means of avoiding the continuous dependency of students on their mother tongue, which, at the same time, provides them with a total exposure to acquire the target language. Instead of that, it should be used as a teaching and learning aid and thus help the students with useful comments, processes and techniques, arising from a translation task, to compensate for their language difficulties.

Koletnik-Korošec (2012) notices and emphasises that monolingual approaches to foreign language teaching have significantly contributed to the almost complete disappearance of translation from ELT/FLT and ESP textbooks, as well as to an - at least declarative - absence of activities involving translation at all levels of institutionalised education in the present time. In her opinion, this comprehensive dismissal of translation has been in part based on the wholesale rejection of the grammar-translation method, but also on more economically and politically motivated grounds, such as the spread of international language schools and the worldwide marketing of course materials and textbooks by various major publishers. She has also made a sharp distinction between pedagogical translation, which implies the translation made and used for pedagogical (educational) purposes and real translation as an act of communication which takes place in real life. In her opinion, pedagogical translation primarily has an instrumental function, in which translation is used as a tool for gaining the information about the language, i.e. for improving the language learner's foreign language proficiency. On the other hand, the object of real translation is information about the content and reality of the source text. The difference also exists in the fact that the addressee of pedagogic translation is 
not the target language reader, as it is the case with real translation, but the teacher, the examiner or the learners themselves.

Kic-Drgas (2014) expresses the opinion that the mutual connection of ESP teaching and specialized translation seems to be the key for optimisation of the teaching process, offering the learners a more complex perspective on the presented issue.

Within an ESP classroom, before actual work on translation in the teaching process, Kic-Drgas stipulates a set of pre-translation exercises and activities, which include:

- reflection about the sender and receiver of the message;

- reflection about the style and register of the written text, with focus on the characteristic features of the text and usage of the specific vocabulary and structures;

- scanning of a given text (finding synonyms, antonyms, etc.),

- preparing of the vocabulary lists connected with a particular subject;

- re-expressing of the content of the given text (also in the mother tongue);

- filling in the gaps with new (specific) words;

- observing and discussing of characteristic features of the specific discourse and

- guessing of the meaning of unknown words from the context.

Pursuant to Kic-Drgas, the process of translation itself should be started with the translation of sentences referring to the certain context, including the repeating of characteristic ESP phrases and terms, so that the students are assisted in assimilating the new vocabulary and encouraged to use it in appropriate context. The next step of translation practice and exercises should be the translating of definitions of certain specific terms into mother tongue, which, at the same time, helps in the memorising of new terms and in the understanding of their meaning. It should be followed by the retranslation of already translated texts, and the final step would be the implementation of the translation of longer texts, serving to acquire new knowledge connected with the specific domain. Such texts should be authentic, not simplified or adopted, especially in terms of focusing on the features of the special discourse in question.

Finally, Kovačević (2015) considers Kic-Drgas's pre-translation exercises as excellent tools to be used, in different situations, as an assistance in the preparational stage of teaching translation to ESP students, comprising only of two steps preceding the actual involvement of students in a true translation process:

- translation of definitions of specific terms and their memorising through the process which should be implemented gradually, starting from more general and widely known terms towards the more specific ones;

- translation of sentences (or smaller paragraphs) referring to the certain context, involving the repeating of characteristic phrases and terms (learned at the first stage) from the vocabulary.

After these two steps, the third stage would involve a gradual introduction of translation of longer texts, where some of the mentioned (pre-translation) activities and exercises may be very useful as well.

\section{TRANSLATION OF PROFESSIONAL AND SCIENTIFIC PAPER TITLES FROM SERBIAN TO ENGLISH AS A PART OF TEACHING ELECTRICAL ENGINEERING AND ICT RELATED ESP}

In present time English language teaching literature, teaching ESP to the students of electrical engineering and ICT has been covered with a great number of books and textbooks which rely on different methods and techniques to introduce the most important and the most 
characteristic features of the language used within the discourse community of persons professionally involved in electrical engineering and ICT. That corpus involves a certain number of books and textbooks written, edited, prepared or compiled especially for the students whose mother tongue is Serbian (the books intended for Croatian students are equally useful, due to the overall similarities of the Serbian and Croatian Language), and some of them are based on syllabi which treat translation, in both directions, as the integral component of an ESP course, so that different materials, exercises and text samples and excerpts are found in them, together with other materials appropriate for various purposes (vocabulary, sentence structures and patterns, discourse organisation, writing of abstract, etc.).

During their studies, and in many cases, after them, the young people involved in the studies of electrical engineering and ICT are often required to write different forms of professional and scientific papers in different professional or vocational subjects, in their mother tongue. Due to a regular and common practice which has been existing in most domestic and regional journals and conference proceedings for a long time, to publish any of such papers it is necessary for them to provide (at least) the translation of the paper title from Serbian into English together with the original text. However, in many cases, such translations are not so easy to make or, from a linguistic and translation perspective, appear to be incorrect or literal. That is why, within the teaching of ESP, a special attention should be paid to that issue.

The translation of titles of professional and scientific papers belonging to the electrical engineering and ICT register from Serbian to English must be observed from two mutually connected perspectives. The first perspective is associated with the overall characteristics of such titles in the source, Serbian language, while the other is in relation with the problems and challenges in their translation.

There are a few essential shared characteristics of the paper titles in the Serbian language, as well as of the papers themselves. Namely, contrary to the titles of books or textbooks, which are usually more precise and generalised, the titles of the papers demonstrate two opposite tendencies: the information presented in them is either too condensed or presented in too much detail (expressed in the number of words), and that, therefore, might cause various difficulties in the creation of a proper translation in English. The other significant feature is the use of terminology appropriate for the register, and within the terminology, the use of Anglicisms is very often and abundant. Finally, and in close relation to the previously mentioned characteristic, there is the use of abbreviations, which are predominantly based on English words, i.e. present the combination of their first letters. In Serbian language, some of them are used in professional and vocational environment so often that they have become pronounced and treated as single words, either pronounced in accordance with the English spelling (ICT, DVD, DTP) or with the Serbian (CD, CAD).

The first problem and challenge in the translation of electrical engineering and ICT related paper titles from Serbian into English is based on the fact that a title, as a concept, implies a complete reduction or absence of additional information and explanation. In other words, all the information, sense and meaning are contained exclusively in the selected words and their linguistic and semantic relations. Due to that, the differences that exist in the systems of Serbian and English language may cause various difficulties and problems, and require additional efforts included in the translation process. Among such efforts, probably the highest amount of attention and care has to be paid to the choice of appropriate terminology which will convey the appropriate meaning of a specific term, expression or phrase. In spite of various bilingual dictionaries that exist, both general and 
specific, and various resources on the Internet, language is alive and subject to constant changes, so that the finding of an appropriate translation equivalent is not always so easy. The use of cases, i.e. their rendering from one language system to another, in the case of Serbian and English might also be a problem, especially if it has too many structures with prepositions (of, for, in, on) as its consequence. On the other hand, the application of the English language grammar property that a noun, or a few nouns, may serve as premodifier(s) to another noun might lead to excessive noun compounding in the translation process, i.e. to the creation of complex noun compounds, by the "piling up" of nouns in the status of premodifiers for the last, "head" noun in front of which they stand.

To evaluate the current and actual situation in terms of the mentioned translation and get the results and conclusions which can be implemented in teaching such translation within appropriate ESP courses, a corpus of already made translations has been created, consisting of 500 titles of professional and scientific papers, published in journals and conference proceedings, originally written in Serbian and translated into English, either by authors or editors. There are no additional data about the content of the papers, in terms of abstract, keywords, text of the paper, etc. For the purpose of the analysis, the corpus items have been alphabetically organised in a table with two columns, one for the title in Serbian and the other for its English translation.

After a detailed analysis of translations, different conclusions have been made, in the range from those obvious ones, visible directly, to the ones which require a deeper insight into both the titles in Serbian and their English translations.

The first of obvious conclusions is that articles are rarely used at the beginnings of titles, while inside them they appear regularly. Also, abbreviations are often not translated in titles and, in such cases, they act (are treated) as Anglicisms. If they are translated, it is done in a rather descriptive manner. Depending on the structure and word order in the titles in Serbian, characteristic patterns are found in their corresponding English translations, such as:

- $\operatorname{noun}(\mathrm{s})+$ of/for $+\operatorname{noun}(\mathrm{s})$;

- $\operatorname{noun}(s)+$ of $+\operatorname{noun}(s)+$ for $+\operatorname{noun}(s)$

- $\operatorname{noun}(\mathrm{s})+($ by) using + noun(s)

- $\operatorname{noun}(\mathrm{s})+$ of/+ noun(s) + (by) using + noun(s) and

- combinations of two or more patterns.

The examples for everything that has been mentioned (omission of articles, treatment of abbreviations, patterns) can be found in Table 1 .

Table 1 Examples for omission of articles, treatment of abbreviations and patterns in translation

\begin{tabular}{|l|l|}
\hline PREGLED RF SIGURNOSNIH STANDARDA IZLAGANJA & OVERVIEW OF RF SAFETY EXPOSURE STANDARDS \\
\hline RAZVOJ JAVA PLATFORME I PROGRAMERSKOG OKRUŽENJA ZA & DEVELOPMENT OF JAVA PLATFORM AND PROGRAMMING \\
NASTAVNO SREDSTVO „INTERFEJS" & ENVIRONMENT FOR THE TEACHING TOOL "INTERFEJS" \\
\hline RAZVOJ SOFTVERA KORIŠCENJEM WEB SERVISA & SOFTWARE DEVELOPMENT USING WEB SERVICES \\
\hline $\begin{array}{l}\text { POBOLŠANJE TAČNOSTI POZICIONIRANJA U USLOVIMA ODSUSTVA } \\
\text { OPTIČKE VIDUIVOSTI PRIMJENOM PSO ALGORITMA OPTIMIZACIJE }\end{array}$ & $\begin{array}{l}\text { IMPROVING ACCURACY OF POSITIONING IN NLOS CONDITIONS } \\
\text { USING PSO OPTIMIZATION ALGORITHM }\end{array}$ \\
\hline
\end{tabular}

Another characteristic of translations of titles is that some terms from the Serbian language sometimes have more than one English translation. In certain cases, such a translation even appears to be incorrect, because the two words, although they sound similarly in two languages, do not have the same meaning, i.e. act as false friends (cases ("realizacija" "realisation", instead of "implementation" as the correct translation). 
Table 2 Examples of Serbian terms having more than one English translation

\begin{tabular}{|ll|}
\hline Serbian & English translation \\
\hline realizacija & realisation, implementation \\
upotreba / upotrebom & use, usage, using / (by) using \\
upravljanje & control, management \\
procjena & assessment, estimation, estimating \\
mogućnosti & possibilities, opportunities \\
unaprijeden & advanced, improved \\
\hline
\end{tabular}

Finally, in terms of noun premodification which can be found in the translations, there are three possible situations:

- premodification with noun(s)

- premodification with adjective(s)

- premodification with adjective(s) and noun(s)

In Table 3, the examples of different types of noun premodification are written in bold:

Table 3 Examples of different types of noun premodification in translation

\begin{tabular}{|l|l|}
\hline $\begin{array}{l}\text { ISPITIVANJE PARAMETARA KVALITETA APLIKACIJE PARKING STANICA } \\
\text { TESTIRANJEM PROGRAMSKIH KOMPONENTII SOFTVERSKOM } \\
\text { METRIKOM }\end{array}$ & $\begin{array}{l}\text { ANALYSIS OF PARKING STATION SOFTWARE QUALITY PARAMETERS } \\
\text { USING COMPONENT TESTING AND SOFTWARE METRICS }\end{array}$ \\
\hline $\begin{array}{l}\text { ALOKACIJA PREKOGRANIČNIH KAPACITETA U SKLADU SA PROPISIMA } \\
\text { EU }\end{array}$ & $\begin{array}{l}\text { CROSS-BORDER TRANSMISSION CAPACITY ALLOCATION IN } \\
\text { ACCORDANCE WITH EU REGULATIONS }\end{array}$ \\
\hline ENERGETSKI EFIKASNE BEŽIČNE SENZORSKE MREŽE & ENERGY-EFFICIENT WIRELESS SENSOR NETWORKS \\
\hline SERVISNO ORIJENTISANO UPRAVLANJE MREŽAMA & SERVICE-ORIENTED NETWORK MANAGEMENT \\
\hline $\begin{array}{l}\text { PRIMENA MODIFIKOVANE FAZNO ZAKLJUČANE PETLE ZA ADAPTACIJU } \\
\text { SISTEMA UPRAVLANJA TEMPERATURNIH PROCESA }\end{array}$ & $\begin{array}{l}\text { APPLICATION OF MODIFIED PHASE-LOCKED LOOP FOR TEMPERATURE } \\
\text { PROCESS CONTROL SYSTEM ADAPTATION }\end{array}$ \\
\hline $\begin{array}{l}\text { ODREĐIVANJE FREKVENCIJSKI ZAVISNIH EKVIVALENTNIH } \\
\text { POLUPREČNIKA DVA SPREGNUTA ALUČEL PROVODNIKA }\end{array}$ & $\begin{array}{l}\text { DETERMINATION OF FREQUENCY DEPENDENT EQUIVALENT } \\
\text { RADIUSES OF TWO COUPLED STEEL CORED ALUMINUM } \\
\text { CONDUCTORS }\end{array}$ \\
\hline
\end{tabular}

Regarding the errors found in translations, there are three identified types: absence of prepositions or use of incorrect prepositions, incorrect or ambiguous word selection and imprecise or incomplete translation which occurs due to the use of retelling or paraphrasing instead of translating or due to the absence of translation of some words from the source.

The errors based on the absence of prepositions or the use of incorrect prepositions in English translation are commonly associated with the incompatibility of preserving and presenting of the relations that exist among the words within a title written in the source (Serbian) language. Several examples are given in Table 4.

Table 4 Examples for absence of prepositions or the use of incorrect prepositions in translation

\begin{tabular}{|c|c|}
\hline $\begin{array}{l}\text { ANALIZA DETERMINANTI ELEKTRONSKE TRGOVINE NA } \\
\text { TRŽISSTU SRBIJE }\end{array}$ & $\begin{array}{l}\text { ANALYSIS OF THE DETERMINANTS (?) ELECTRONIC } \\
\text { TRADING ON THE SERBIAN MARKET }\end{array}$ \\
\hline RAZLIKE CRM I E-CRM POSLOVNE STRATEGIJE & $\begin{array}{l}\text { DIFFERENCES (?) CRM AND E-CRM BUSINESS } \\
\text { STRATEGY }\end{array}$ \\
\hline $\begin{array}{l}\text { AKVIZICIJA I PRENOS PODATAKA OD MALE } \\
\text { HIDROELEKTRANE DO DISPEČERSKOG CENTRA }\end{array}$ & $\begin{array}{l}\text { ACQUISITION AND TRANSMISSION (?) DATA FROM A } \\
\text { SMALL HYDROELECTRIC PLANT TO A DISPATCHING } \\
\text { CENTER }\end{array}$ \\
\hline $\begin{array}{l}\text { ENTROPIJA I SEKVENCIJALNA ANALIZA } \\
\text { PORTAPRES`SIGNALA }\end{array}$ & $\begin{array}{l}\text { ENTROPY AND SEQUENCE ANALYSIS IN PORTAPRES }{ }^{\circledR} \\
\text { SIGNALS }\end{array}$ \\
\hline
\end{tabular}


In the first three examples, a preposition is completely absent (the (?) sign marks the place where it should be) so that the entire translation is wrong, both in terms of grammar and its semantics. In the fourth case, the wrong preposition "in" has been used instead of "of" as the appropriate one, thus changing in translation the meaning and relations between the words which exist in the source text.

Incorrect or ambiguous word selection also has various negative consequences to the rendering of meaning in translation from the source language to the target language. Some examples are presented in Table 5.

Table 5 Examples of ambiguous word selection in translation

\begin{tabular}{|l|l|}
\hline $\begin{array}{l}\text { INFORMACIONE TEHNOLOGIJE U NEFORMALNOM } \\
\text { UČENJU }\end{array}$ & IT TECHNOLOGIES IN INFORMAL TEACHING \\
\hline $\begin{array}{l}\text { PRAVNA REGULATIVA DIGITALNOG EMITOVANJA RADIO I } \\
\text { TELEVIZIJSKOG PROGRAMA U REPUBLICI SRBIII }\end{array}$ & $\begin{array}{l}\text { LAW REGULATION OF DIGITAL BROADCASTING OF RADIO } \\
\text { AND TELEVISION PROGRAMS IN THE REPUBLIC OF SERBIA }\end{array}$ \\
\hline KREIRANJE ANIMACIJA UPOTREBOM ADOBE FLASH-A & CREATING ANIMATION USING FLASH PLAYER \\
\hline $\begin{array}{l}\text { SIGURNOSNI ASPEKTI SERVISNO ORIJENTISANIH } \\
\text { ARHITEKTURA }\end{array}$ & $\begin{array}{l}\text { SERVICE-ORIENTED ARCHITECTURE SECURITY } \\
\text { VULNERABILITIES }\end{array}$ \\
\hline
\end{tabular}

In the first of them, the word "teaching" has been used incorrectly as the translation of "učenju", instead of "learning" as an appropriate translation. In the second example, probably through the visual association based on the similarity of the words in two languages (false friends), "law regulation" (implying only one regulation, or, in Serbian, "propis") has been used as a translation for "zakonska regulativa" instead of the correct term "legislation". In the third case, there is no actual translation, because English words are used both in source and its translation, but in an incorrect manner, because "Adobe Flash" software (use for making of animations) is not the same as "Flash Player" software (used for playing/displaying of animations). Finally, in the fourth case, the Serbian word "aspekti" has been translated as "vulnerabilities" (meaning "propusti" or "ranjivosti") instead of the use of "aspects" as appropriate translation, so that it can be said that the meaning of source has been altered in the translation.

Some translations found within the corpus have been identified as imprecise or incomplete. The impreciseness and incompleteness usually occur due to the use of paraphrasing or retelling instead of translating (Table 6) or the omission of words from the translation (Table 7).

Table 6 Examples of translations which are incomplete or incorrect due to the use of paraphrasing/retelling

\begin{tabular}{|l|l|}
\hline $\begin{array}{l}\text { PRIMENA NELINEARNOG UPRAVLJANJA SA AKTIVNIM } \\
\text { POTISKIVANJEM POREMEĆAJA U SISTEMU POZICIONIRANJA } \\
\text { LASERSKE PRATEĆE GLAVE ZA SAMOVOĐENJE RAKETE }\end{array}$ & $\begin{array}{l}\text { NONLINEAR ACTIVE DISTURBANCE REJECTION CONTROL OF } \\
\text { ROCKET LASER SEEKER SYSTEM }\end{array}$ \\
\hline $\begin{array}{l}\text { PRIMJENA MATLAB-A U ANALIZI VIŠIH HARMONIKA } \\
\text { PERIODIČNOG SIGNALA }\end{array}$ & HARMONIC ANALYSIS OF PERIODIC SIGNALS BY MATLAB \\
\hline $\begin{array}{l}\text { PROGRAMSKA REŠENJA PRI PROCENI BROJA PI MONTE } \\
\text { CARLO METODAMA UZ INTERAKTIVNE ANIMACIJE }\end{array}$ & $\begin{array}{l}\text { PI APPROXIMATION USING MONTE CARLO METHOD WITH } \\
\text { INTERACTIVE ANIMATIONS REALIZED IN DIFFERENT } \\
\text { PROGRAMMING ENVIRONMENTS }\end{array}$ \\
\hline
\end{tabular}

As it can be seen, the paraphrasing or retelling essentially preserves the basis of the information from the source, but it is still imprecise and does not display all the details which would have been clear and visible if the titles had been truly translated instead. 
It is similar in the case of words missing from translation, where the omitted words are, usually, considered and treated as not so important for the essence of information contained in a title. However, observed from the translation perspective, such translations are incomplete and thus incorrect as well. In Table 7, the words whose translations are omitted are written in bold.

Table 7 Examples of translations which are incomplete or incorrect due to the omission of words

\begin{tabular}{|l|l|}
\hline $\begin{array}{l}\text { PROTOKOL KOMUNIKACIJE NOVOG MEDICINSKOG LASERA } \\
\text { SA NADREĐENIM RAČUNAROM }\end{array}$ & NEW MEDICAL LASER TO PC COMMUNICATION PROTOCOL \\
\hline $\begin{array}{l}\text { IMS - ŠANSA ZA KONVERGENCIJU FIKSNIH I MOBILNIH } \\
\text { MREŽA }\end{array}$ & IMS - A CHANCE FOR FIXED-MOBILE CONVERGENCE \\
\hline $\begin{array}{l}\text { MODULARNA HARDVERSKA ARHITEKTURA ZA AES } \\
\text { ALGORITAM }\end{array}$ & $\begin{array}{l}\text { MODULAR AES HARDWARE ARCHITECTURE } \\
\text { (AES - Advanced Encryption Standard) }\end{array}$ \\
\hline UGOVARANJE SLA ZA MOBILNE SERVISE & $\begin{array}{l}\text { SLA FOR MOBILE SERVICES } \\
\text { (SLA - Service Level Agreement) }\end{array}$ \\
\hline
\end{tabular}

All the data obtained from the analysis are a valuable resource for the teaching of electrical engineering and ICT students how to deal with the translation of professional and scientific paper in the best possible manner. Pursuant to the analysis results, such teaching would involve a few steps.

The first step would be the presentation of all the features, patterns and errors identified within the corpus.

At the second step, the students would be given the appropriate examples of translations so that they can recognise the features, patterns and/or errors within them.

Then, at the third step, they would be presented some examples of well-performed translations, with a detailed description and explanation of the translation solutions which make such translations good and exemplary.

The final step would, of course, be the actual performance of translation of titles by students. In doing that, they would be required to follow a few important principles.

The first of such principles is a consistent use of translated terminology, accomplished by careful and persistent search for appropriate translation equivalents.

Another significant principle is that ambiguity in translation has to be fully avoided, because only the use of clear and unambiguous word meanings may produce appropriate and quality translations.

Prepositions have to be used with care and with good knowledge of all their possible meanings as well as of the relations which they might represent. On the other hand, all the used forms of noun premodification or noun compounding have to be completely understandable and unambiguous.

Finally, the efforts have to be put in translating all the words from a title, while, at the same time retelling or paraphrasing instead of translating should be avoided, so that the information and meaning(s) are completely transferred from the source language (Serbian) to the target language (English).

\section{OVERVIEW AND CONCLUSIONS}

For many reasons, translation has proved to be a significant component in teaching ESP at higher education institutions. It is especially the case with the ESP related to 
electrical engineering and ICT, due to the fact that English has been the overall language of engineering and technology for a very long time. In the case of students (learners) with Serbian as their mother tongue, the insisting on translation within ESP lessons is especially significant, in order for them to be aware of all the terminological, grammatical and other differences which exist between Serbian and English and are relevant for all forms of professional communication in the fields of electrical engineering and ICT.

During their studies and, consequently, later in professional careers, persons involved in electrical engineering and ICT often write different forms of papers in their mother tongue. Because of objective publication needs and requirements which exist in present time, it is usually necessary for them to translate (at least) the titles of such papers into English. That is why it is important to integrate the translation of such titles into translation teaching within ESP.

The analysis of a corpus of different authentic translations of titles of professional and scientific papers from the register of electrical engineering and ICT has given the detailed information on the way in which such a translation has been performed in practice, including the key features, patterns and possible errors which occur in the translation process. Such information is a valuable resource for the setting of steps towards a successful translation of the titles to be implemented within the translation component of the ESP teaching process. Only through the following of such steps, can the translation be made in appropriate and correct manner, and, at the same time, can a firm and persistent knowledge on various linguistic issues from the target (English) language be acquired.

\section{REFERENCES}

Benabdallah, A. (2013). The Role of Translation in the ESL/EFL and ESP Classroom Teaching ESP through Translation: A Key for Teaching Specialized Communication. English for Specific Purposes World, Issue 37, vol. 13, 2013. Available online at http://www.esp-world.info/Articles_37/benabdallah_Translation.pdf, accessed on 27 February 2019.

Kic-Drgas, J. (2014). Translation in the ESP Teaching, The Journal of Teaching English for Specific and Academic Purposes, Vol. 2, No 2, 2014. pp. 253-261.

Koletnik-Korošec, M. (2012). The Role of Translation in the ESL/EFL and ESP Classroom. The International Language Conference on the Importance of Learning Professional Foreign Languages for Communication between Cultures. Celje - Slovenia, September 2012. Available online at: http://www.researchgate.net/publication/255893511_The_ Role_of_Translation_in_the_ESLEFL_and_ESP_Classroom, accessed on 27 February 2019.

Kovačević, D. (2015). Translation as a Part of Teaching ESP at an Academy of Music, in: N. Stojković and V. Nejković (eds.), Synergies of Language Learning, Proceedings of the 2nd International Conference on Teaching English for Special Purposes and New Language Learning. Niš: Faculty of Electronic Engineering. pp 59-67

Prudnikova, N. N. (2013). Some Aspects of Intense ESP Translation Teaching. SSRN. Available online at http://ssrn.com/abstract=2232206, accessed on 27 February 2019. 